\title{
ANALISIS PENDAPATAN PETANI SAYUR SAWI DI KECAMATAN PAAL MERAH KOTA JAMBI \\ Oleh:
}

\author{
Abd Halim ${ }^{1}$ \\ Dosen Tetap STIE Muhammadiyah Jambi ${ }^{1}$ \\ abdhalim925@yahoo.co.id \\ Suherman $^{2}$ \\ Dosen Tetap STIE Muhammaadiyah Jambi² \\ suhermanrika17@gmail.com
}

\begin{abstract}
Abstrak
Penelitian ini bertujuan untuk mengetahui Bagaimanakah karakteristik petani sayur sawi di kecamatan paal merah Kota Jambi Dan Faktor - faktor apa saja yang mempengaruhi pendapatan petani sayur sawi di kecamatan paal merah Kota Jambi yang terdiri dari 100 responden yang dilakukan melalui sample.metode yang di gunakan adalah melaui kuesioner dan wawancara dan data lapangan selanjutnya menggunakan SPSS versi 17 jenis komputer analisis data yang digunakan adalah terdiri dari deskriftif yang meliputi penentuan korelasi berganda dan regresi linier berganda. Hasil penelitian ini menunjukan dapat diterjemahkan bahwa setiap penambahan variable X1 (jam kerja) sebesar 1 persen maka akan menambah pendapatan petani sayur di kecamatan paal merah sebesar 0,463\%. setiap penambahan variable X2 (tenaga kerja) sebesar 1 persen maka akan meningkatkan pendapatan petani sayur di kecamatan paal merah sebesar 0,354\% dan apabila terjadi kenaikan variabel X3 (modal kerja) sebesar 1 persen akan semakin meningkat pendapatan petani sayur kecamatan paal merah sebesar 0,509\%.
\end{abstract}

Kata Kunci : Jam Kerja, Tenaga Kerja, Modal Kerja dan Pendapatan

\section{PENDAHULUAN}

Salah satu hal yang penting dalam sektor pertanian adalah sektor pangan. Ketersediaan sektor pangan menjadi sangat penting seiring dengan pertumbuhan masyarakat yang ada di Indonesia. Berdasarkan Sensus Penduduk tahun 2015, jumlah penduduk di Indonesia mencapai 257,9 juta jiwa. Hal ini harus di dukung oleh adanya pemerintah untuk meningkatkan hasil produksi sayuran yang ada di Indonesia.

Jika di lihat dari iklim dan kondisi tanah yang ada di Provinsi Jambi cocok untuk di tanamin cabai, timun, tomat, kacang panjang, jagung manis. Tanaman ini tidak membutuhkan banyak air serta pemeliharaannya sehingga sangat cocok bagi petani yang ada di Jambi menurut Afrizal Gindow (2013).

Penerimaan data yang tertinggi yakni terdapat pada seledri Rp 50.466.000,- dengan keuntungan finansial Rp 38.004.446,- , sedangkan penerimaan terendah terdapat pada sayuran selada Rp 2.700.00,- di dapat melalui (Media Cetak, Regional Jakarta ).

Kegiatan kelompok tani Sido Makmur ini merupakan salah satu kelompok tani yang ada di Kota Jambi yang berada pada kawasan paal merah lama kecamatan jambi selatan Kota 
Jambi. Sejak tahun 1986, masyarakat sekitar telah bergabung dengan kolompok petani tersebut dan melakukan kegiatan bercocok tanam.

Tingkat pendapatan dalam suatu masyarakat masih di ukur dalam kesejahteraan masyarakat dan status soaial. Semakin tinggi tingkat pendapatan seseorang biasanya memiliki kesejahteraan masyarakat dan status sosial yang tinggi pula. Sementara itu tingkat kesejahteraan sangat berkaitan dengan pendapatan masing-masing masyarakat, termasuk di dalamnya adalah petani sayuran di kecamatan paal merah kota jambi.

Perbedaan tingkat pendapatan pada akhirnya akan menyebabkan ketimpangan dalam distribusi pendapatan yang berpengaruh dalam kesejahteraan petani sayur.

Adanya dari persoalan di atas, maka dapat di rumuskan suatu permasalahan yang akan di bahas yakni: (1) Bagaimanakah karakteristik petani sayur sawi di kecamatan paal merah Kota Jambi. (2) Faktor - faktor apa saja yang mempengaruhi pendapatan petani sayur sawi di kecamatan paal merah Kota Jambi.

\section{Landasan Teori}

Secara luas pertanian adalah semua yang mencangkup kegiatan pertanian (tanaman pangan dan hortikultura), perkebunan, kehutanan, peternakan dan perikanan. Sedangkan pertanian dalam arti sempit adalah suatu budidaya tanaman ke dalam suatu lahan yang bertujuan untuk mencukupi kebutuhan manusia.

\section{Skema kerangka pemikiran :}

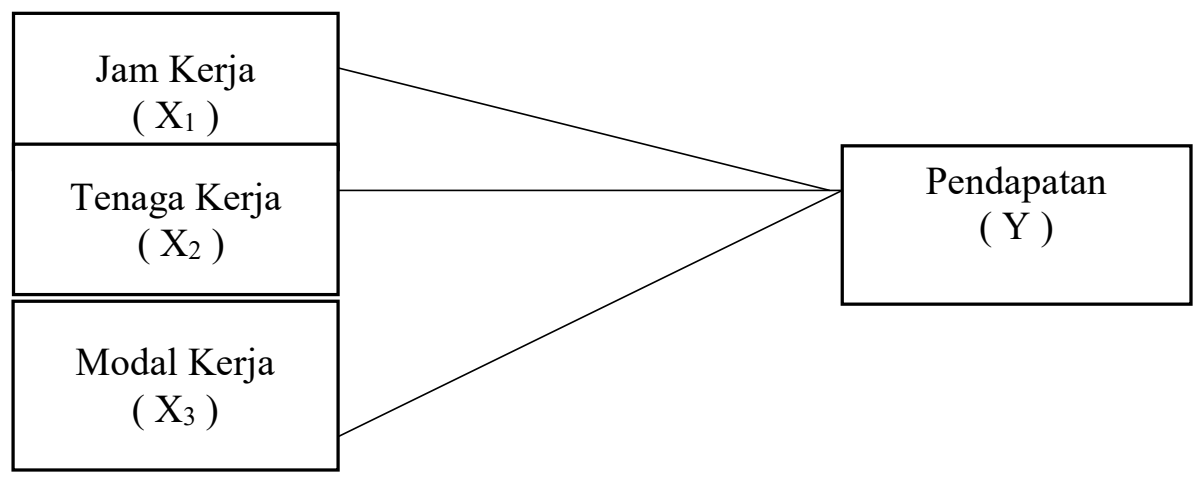

\section{METODE PENELITIAN}

Metode yang digunakan dalam penelitian ini adalah deskriptif kualitatif dan kuantitatif.

\section{Populasi dan Sampel}

Sampel adalah sebagian atau wakil populasi yang diteliti. Jika subjek kurang dari 100, lebih baik diambil semua sehingga penelitiannya merupakan penelitian populasi dan jika subjek besar dapat diambil antara $10-15 \%$ atau 20-25\%. 


\section{Metode Analisis Data}

$\mathrm{Y}=\mathrm{f}(\mathrm{L}, \mathrm{K}, \mathrm{T})$

$\mathrm{Y}=\beta_{0} L^{\beta 1} \quad \mathrm{~K}^{\beta 2} \mathrm{~T}^{\beta 3} \mathrm{e}^{\beta 2 \mathrm{~T}+\mu}$

Untuk melinierkan variabel tersebut maka digunakan logaritma natural sebagai berikut :

$$
\log Y=\log \alpha+\beta_{1} \log X_{1}+\beta_{2} \log X_{2}+\beta_{3} \log X_{3}+\mu
$$

Di mana ;

$$
\begin{array}{ll}
\mathrm{Y} & =\text { Pendapatan } \\
\mathrm{X}_{1} & =\text { Modal Kerja } \\
\mathrm{X}_{2} & =\text { Jam Kerja } \\
\mathrm{X}_{3} & =\text { Tenaga Kerja } \\
\alpha & =\text { Konstanta } \\
\beta 1 & =\text { Koofisien regresi } \\
\mu & =\text { error term }
\end{array}
$$

\section{HASIL PENELITIAN}

\section{1) Umur}

Umur merupakan salah satu perkembangan orang untuk memilih dan melakukan pekerjaan. Umur juga bisa dijadikan ukuran kematangan emosional seseorang. Umur juga mempengaruhi produktivitas seseorang. Umur yang lebih mudah akan memiliki tenaga yang lebih kuat di bandingkan mereka yang memiiki umur yang lebih tua. Namun demikian tidak selamanya mereka yang berumur lebih muda memiliki produktivitas lebih tinggi dibandingkan mereka yang berusia yang lebih tua.

\section{2 ) Jumlah Anggota Keluarga}

Jumlah anggota keluarga dapat mencerminkan berapa besar biaya yang dipergunakan untuk keperluan keluarga. karena itu secara langsung besarnya anggota keluarga mencerminkan juga besarnya pengeluaran yang harus dikeluarkan oleh sebuah keluarga. Semakin besar jumlah anggota keluarga, maka semakin besar biaya yang dikeluarkan agar kebutuhan keluarga dapat terpenuhi.Namun demikian bukan berarti mereka yang memiliki jumlah keluarga yang lebih kecil tidak giat dalam melakukan pekerjaannya.

\section{3 ) Tingkat Pendidikan Responden}

Tingkat pendidikan dapat mempengharuh pola pikir dan kedewasaan seseorang biasanya semakin tinggi tingkat pendidikan seseorang maka akan semakin maju pola pikirnya dalam bekerja dan berusaha mengembangkan tanahnya. Namun tidak selalu 
demikian kenyataannya, kadang-kadang mereka berpendidikan rendah pun memiliki pola piker yang maju. faktor pengalaman hidup kadang-kadang melebihi tingkat pendidikannya yang disandang oleh seseorang. semakin luas pengalaman hidup seseorang akan semakin terlatih dalam menghadapi berbagai persoalan yang dihadapinya.

\section{4) Lamanya Bertani Sayur Sawi}

Lama usaha setiap petani sayur sawi berbeda-beda, secara teori lama usaha akan memepengaruhi pertumbuhan dan keberhasilan pengembangan usaha, karena petani sayur sawi yang telah berkegiatan lama akan banyak mendapatkan pengalaman tentang teknis pengelolaan usahanya.

\section{5) Responden Menurut Status Pekerjaan}

Kemampuan memproduksi baik secara kualitas setiap usaha petani sayur sawi ini berbeda, hal ini terkait dengan modal yang digunakan dari dan sumberdaya yang dimilikinya. Semakin besar modal maka semakin besar pula jumlah produksi yang dihasilkan.

\section{6) Responden Menurut Luas Tanaman Sawi}

Luas tanaman yang di miliki oleh petani sayur sawi di kelurahan ekajaya kecamatan paal merah kota jambi,memiliki luas lahan yang berbeda - beda. Dimana luas lahan merupakan salah satu faktor produksi penting dalam usaha meningkatkan produksi yang dapat mempengaruhi pendapatan dan keuntungan petani.

\section{7) Responden Menurut Jam Kerja}

Jam kerja mempengaruhi pendapatan nelayan, dimana semakin lama petani melakukan aktivitas bertani akan berpengaruh terhadap hasil panen sayur sawi tersebut.

\section{8) Responden Menurut Tenaga Kerja}

Tenaga Kerja yang di miliki oleh petani sayur sawi di kelurahan ekajaya kecamatan paal merah kota jambi,memiliki tenaga kerja hampir sama. Dimana tenaga kerja merupakan salah satu faktor produksi penting dalam usaha meningkatkan hasil panen yang dapat mempengaruhi pendapatan dan keuntungan petani.

\section{Faktor-faktor yang mempengharuhi pendapatan petani sayur sawi}

Dengan menggunakan bantuan komputer, maka diperoleh hasilpengujian regresi. Dari hasilhasil pengujian tersebut dapat ditafsirkan sebagai berikut : 


\begin{tabular}{|c|c|c|c|c|c|}
\hline \multirow[b]{2}{*}{ Model } & \multicolumn{2}{|c|}{$\begin{array}{c}\text { Unstandardized } \\
\text { Coefficients }\end{array}$} & \multirow{2}{*}{\begin{tabular}{|c|}
$\begin{array}{c}\text { Standardized } \\
\text { Coefficients }\end{array}$ \\
Beta \\
\end{tabular}} & \multirow[b]{2}{*}{$\mathrm{T}$} & \multirow[b]{2}{*}{ Sig. } \\
\hline & $\mathrm{B}$ & Std. Error & & & \\
\hline $1 \quad$ (Constant) & 2,201 & ,378 & & 5,831 &, 000 \\
\hline Jam Kerja & ,463 &, 146 &, 265 & 3,172 &, 003 \\
\hline $\begin{array}{l}\text { Tenaga } \\
\text { Kerja }\end{array}$ & ,354 & ,192 &, 167 & 1,847 &, 071 \\
\hline $\begin{array}{l}\text { Modal } \\
\text { Kerja }\end{array}$ &, 509 &, 067 & ,594 & 7,631 &, 000 \\
\hline
\end{tabular}

Dependent Variable: Pendapatan Petani Sayur Sawi

$\mathrm{Y}=$ 2,201 + 0,463 Jam Kerja + 0,354 Tenaga Kerja + 0,509 Modal Kerja

Dari persamaan regresi diatas dapat diterjemahkan bahwa setiap penambahan variable X1 (jam kerja) sebesar 1 persen maka akan menambah pendapatan petani sayur di kecamatan paal merah sebesar $0,463 \%$. setiap penambahan variabel X2 (tenaga kerja) sebesar 1 persen maka akan meningkatkan pendapatan petani sayur di kecamatan paal merah sebesar $0,354 \%$ dan apabila terjadi kenaikan variabel X3 (modal kerja) sebesar 1 persen akan semakin meningkat pendapatan petani sayur kecamatan paal merah sebesar 0,509\%.

Pengujian Hipotesis

Pengujian dilakukan untuk mengetahui apakah semua variabel independent ( jam kerja,tenaga kerja dan modal kerja) berpengaruh terhadap variabel depedent ( pendapatan petani sayur sawi). Dalam pengujian hipotesis terdapat variasi antara nilai variabel dependent yang dijelaskan oleh variabel independent, dilakukan perumusan hipotesis yaitu :

Berdasarkan 5.2.2 Uji-F (Anova) yaitu dengan derajat kebebasan maka diperoleh $\mathrm{f}_{\text {hitung }}$ sebesar 90,296 sedangkan $\mathrm{f}_{\text {tabel }}$ sebesar 2,194 yang diperoleh melalui perhitungan statistik perhitungan menunjukan bahwa ternyata nilai $f_{\text {hitung }}$ lebih besar dari nilai $f_{\text {tabel }}(90,296>2,194)$ maka, $\mathrm{H}_{\mathrm{o}}$ ditolak dan menerima hipotesis $\mathrm{H}_{\mathrm{a}}$ pada tingkat keyakinan $90 \%(\alpha=10 \%)$. Hal ini berarti semua variabel independent atau variabel bebas ( jam kerja,tenaga kerja dan modal kerja) secara bersama - sama (secara simultan) berpengaruh terhadap variabel dependent atau variabel terikat ( pendapatan petani sayur sawi ) dengan tingkat signifikan sebesar $0.000<0.10$ menunjukan signifikan nya variabel independent terhadap variabel dependent dengan kata lain setiap perubahan variabel bebas (independent) akan mempengaruhi pendapatan petani sayur sawi.

\section{Uji t (pengujian terhadap koefisian regresi parsial)}


Uji statistik t pada dasar nya menunjukan seberapa jauh pengaruh satu variabel bebas secara individu dalam menerapkan variasi variabel terikat (Kuncoro,2003). Nilai dalam pengujian hipotesis terhadap koefisien regresi secara parsial di tentukan dengan menggunakan tabel distribusi normal dengan tingkat signifikasi $(\alpha=10 \%)$ dengan tingkat kepercayaan 90\% maka diperoleh hasil sebagai berikut:

\section{a. Variabel $X_{1}$ ( Jam Kerja )}

Pada variabel $\mathrm{X}_{1}$ ( Jam Kerja ) di ketahui nilai thitung nya adalah sebesar 3,172 dan tabel sebesar 1,675 dengan melihat perbandingan kecilnya thitung Jam Kerja dari pada tabel maka dapat diketahui bahwa thitung lebih kecil dari pada $t_{\text {tabel }}(3,172>1,675)$ atau $t_{\text {hitung }}$ berada di daerah penerimaan $\mathrm{H}_{\mathrm{a}}$, dengan tingkat signifikan sebesar 0.003 yang berarti pada tingkat keyakinan 90\% variabel X1 jam kerja signifikan artinya terdapat pengaruh antara jam kerja terhadap pendapatan petani sayur sawi.

\section{b. Variabel X2 ( Tenaga Kerja )}

Pada variabel X2 ( tenaga kerja ) diketahui bahwa nilai thitung nya adalah sebesar 1,847 dan $t_{\text {tabel }}$ sebesar 1,675. Dengan melihat perbandingan $t_{\text {hitung }}$ tenaga kerja dari pada $t_{\text {tabel }}$ maka dapat diketahui bahwa $t_{\text {hitung }}$ lebih besar dari $t_{\text {tabel }}(1,847>1,675)$ atau thitung berada di daerah penerimaan $\mathrm{H}_{\mathrm{a}}$ dengan tingkat signifikan sebear 0.071 yang berarti pada tingkat keyakinan 90\% variabel X2 ( tenaga kerja ) signifikan artinya terdapat pengaruh antara tenaga kerja terhadap pendapatan petani sayur sawi.

\section{c. Variabel X3 ( Modal Kerja)}

Pada variabel X3 ( Modal Kerja ) diketahui bahwa nilai $t_{\text {hitung nya adalah sebesar 7,631 }}$ dan $t_{\text {tabel }}$ sebesar 1,675. Dengan melihat perbandingan thitung Modal Kerja dari pada tabel maka

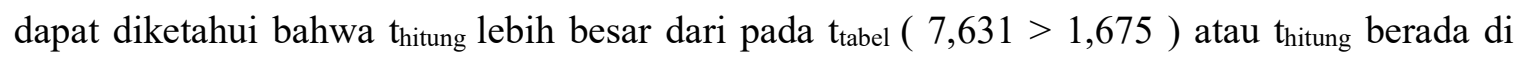
daerah penerimaan $\mathrm{H}_{\mathrm{a}}$ dengan tingkat signifikan sebesar 0,000 yang berarti pada tingkat keyakinan 90\% variabel X3 ( Modal Kerja ) signifikan artinya terdapat pengaruh antara modal kerja terhadap pendapatan petani sayur sawi.

Berdasarkan tabel 5.2.3 dapat dilihat bahwa nilai koefisien determinasinya ( $\mathrm{R}$ square) sebesar 0,842 yang mengandung arti seluruh variabel bebas jam kerja ,tenaga kerja, modal kerja $(\mathrm{X} 1, \mathrm{X} 2, \mathrm{X} 3)$ secara bersamaan dapat menerangkan variabel pendapatan petani (Y) yakni yang menunjukan 84,2 persen. sementara sisa sebesar 15,8 persen diterangkan oleh variabel lainnya yang tidak diteliti dalam penelitian ini. 


\section{KESIMPULAN}

Dari hasil penelitian dan pembahasan ada beberapa hal dapat disimpulkan, yaitu:

1. Masyarakat yang bekerja sebagai petani sayur dilihat dari usia respondennya berumur antara 27 sampai 83 tahun, serta jumlah anggota keluarga yang mereka miliki dimulai dari 2 sampai 7 anggota keluarga, masing masing petani sayur sawi memiliki tenaga kerja sebanyak 2 sampai 3 tenaga kerja yang dipergunakan dalam melakukan hasil panen sawi per bulannya, tingkat pendidikan yang dimiliki mulai dari SD sampai S1, hal ini semua sangat mempengharuhi jumlah produksi sayur sawi di Kecamatan Paal Merah Kota Jambi dengan responden sebanyak 55 maka dapat memberikan gambaran petani sayur sawi di Kecamatan Paal Merah Kota Jambi.

2. Setiap penambahan variabel X1 (Jam Kerja ) sebesar 1 persen akan pendapatan petani sayur sawi sebesar 0,463\%. Sedangkan setiap penambahan 1 persen variabel X2 (Tenaga Kerja) akan semakin meningkatkan pendapatan petani sayur sawi sebesar 0,354\%. setiap penambahan 1 persen variabel X3 (Modal Kerja) akan semakin besarpendapatan petani sayur sawi sebesar 0,509\%. Nilai determinasinya ( $R$ square) sebesar 0,842 yang mengandung arti seluruh variabel bebas jumlah tenaga kerja, modal kerja, jam kerja $(\mathrm{X} 1, \mathrm{X} 2, \mathrm{X} 3$ ) secara bersamaan dapat menerangkan variabel pendapatan petani sayur sawi (Y) yakni yang menunjukan 84,2 persen. sementara sisa sebesar 15,8 persen diterangkan oleh variabel lainnya yang tidak diteliti dalam penelitian ini. Seperti tiingkat pendidikan, lama usaha dan luas tanaman sayur sawi.Koefisien korelasi dipergunakan untuk melihat keeratan hubungan antara variabel $\mathrm{X}$ dan $\mathrm{Y}$.

\section{DAFTAR PUSTAKA}

Ahyari, Agus. 2001. Managemen Produksi : perencanaan sistem produksi, edisi ke 5, cetakan ke 4. Jakarta

Arikunto, Suharsimi. 2006. Metodologipenelitian. Yogyakarta: Bina Aksara

Dinas Pertanian Jambi. 2010. Jambi, media elektronik ( www.google.com ).

Dodi Normansyah, Dkk. 2014. Analisis Pendapatan Usahatani Sayuran Di Kelompok Tani Jaya, Desa Ciaruteun Ilir, Kecamatan Cibungbulang, Kabupaten Bogor. Jurnal Agribisnis, Vol. 8, No. 1, Juni 2014. Bogor.

Harahap, sofyan Syafri. 2009 . Teori Kritis Laporan Keuangan. Jakarta: Bumi Aksara 
Rahim. A dan Hastuti, D. R. D. 2007. Pengantar Teori dan Kasus Ekonomi Pertanian. Seri Agriwawasan. PT. Penerba Swadaya. Jakarta

Ria Aswita Poohan. 2008. Analisis usahatani dan faktor-faktor yang mempengaruhi pendapatan petani wortel. Universitas Sumatera Utara. Medan

Safitri Sirly Laras. Analisis Pendapatan Usahatani Kubis Bunga Di Desa Gandasari Kecamatan Cikaum Kabupaten Subang. Jurnal Agrorektan: Vol 2 No. 1 Juni 2015. Subang.

Soekartawi dkk. 2003. Analisis Usahatani. UI - Press. Jakarta.

Sumarni, Murti dan John Soeprihanto. 2010. Pengantar Bisnis (Dasar-dasar Ekonomi Perusahaan). Edisi ke 5. Yogyakarta: Liberty Yogyakrta

Suprayitno. 2015 . Faktor - Faktor Yang Mempengaruhi Pendapatan Usahatani Cabai Merah. Fakultas Pertanian Universitas Bojonegoro.Jawa Timur

Suratiyah K. 2009. Ilmu Usahatani cetakan ke 3.Jakarta(ID):PenebarSwadaya

Sukirno. Sadono. 2006. Ekonomi Pembangunan. Proses, Masalah dan Kebijakan, Kencana Prenada Media Group.

Tim Dosen Pengantar Usahatani. 2013. Modul Praktikum Pengantar Usahatani Laboratorium Manajemen dan Analisis Agribisnis. Malang: Fakultas Petanian Universitas Brawijaya. 